\title{
Availability of calcium from skim milk, calcium sulfate and calcium carbonate for bone mineralization in pigs
}

\author{
Alain PointillarT ${ }^{a *}$, Véronique COXAM $^{\mathrm{b}}$, Bernard SÈVE ${ }^{\mathrm{c}}$, \\ Colette COLIN ${ }^{\mathrm{a}}$, Claire H. LACROIX ${ }^{\mathrm{a}}$, Léon GUÉGUEN ${ }^{\mathrm{a}}$ \\ ${ }^{a}$ Laboratoire de Nutrition et Sécurité Alimentaire, INRA, 78352 Jouy-en-Josas, France \\ ${ }^{\mathrm{b}}$ Unité maladies métaboliques et micronutriments, INRA-Theix, \\ 63122 Saint-Genès-Champanelle, France \\ ${ }^{c}$ Station de recherches porcines, INRA, 35390 Saint-Gilles, France
}

(Received 9 October 1999; accepted 19 November 1999)

\begin{abstract}
Dairy products provide abundant, accessible calcium for humans, while some calcium sulfate-rich mineral waters could provide appreciable amounts of calcium. But there is little evidence that this calcium is as available as milk calcium for making bone. The availability of calcium was studied by monitoring bone parameters in 2-month-old pigs fed restricted amounts of calcium (70\% RDA) for 2.5 months. The 3 main ( $\geq 50 \% \mathrm{Ca}$ intake) $\mathrm{Ca}$ sources were either $\mathrm{CaCO}_{3}$ or $\mathrm{CaSO}_{4}$ or skim milk powder ( $29 \%$ of the diet). The bones of the pigs fed the "milk" diet had higher $(P<0.01)$ ash contents, breaking strength and density (DEXA) than those of the two others groups, in which the bone values were similar. Thus, the calcium provided by a diet containing milk appears to ensure better bone mineralization than do calcium salts included in a non-milk diet. The calcium restriction may have enhanced some milk properties to stimulate calcium absorption in these young, rapidly growing pigs.

calcium availability / calcium sulfate / milk calcium / bones / pigs
\end{abstract}

Résumé - Biodisponibilité comparée du calcium du lait, du sulfate et du carbonate de calcium pour la minéralisation osseuse: étude chez le porc. Le sulfate de calcium, dont certaines eaux minérales sont riches, est-il aussi bien utilisé pour la minéralisation osseuse que le calcium des produits laitiers ? Trois lots de 8 porcs, de 2 mois, recevaient pendant 2,5 mois, trois régimes dont au moins $50 \%$ de l'apport calcique était fourni par $\mathrm{CaSO}_{4}, \mathrm{CaCO}_{3}$ ou la poudre de lait. Bien que différents dans leur composition, les trois régimes étaient formulés pour avoir la même valeur nutritionnelle et leur teneur en $\mathrm{Ca}$ était restreinte (70 \% des recommandations). Avec le régime « lait », les cendres, la résistance à la rupture et la densité minérale des os étaient supérieures à celles des deux autres groupes, non différents l'un de l'autre. L'analyse des paramètres circulants liés au métabolisme osseux (en particulier au collagène), des 3 groupes, exclut l'hypothèse d'un effet direct de la source

* Correspondence and reprints

E-mail: pointil@jouy.inra.fr 


\begin{abstract}
de calcium sur la formation ou la résorption osseuse. En revanche, la phosphatasémie plus élevée, avec le régime « lait» qu'avec les deux autres, est cohérente avec une stimulation éventuelle de l'accrétion osseuse liée à une disponibilité plus grande de $\mathrm{Ca}$ et $\mathrm{P}$. La restriction calcique pourrait avoir exacerbé certaines propriétés des composantes du lait chez ces jeunes porcs à très forte vitesse de croissance.
\end{abstract}

calcium du lait / sulfate de calcium / os / modèle porc / biodisponibilité

\section{INTRODUCTION}

There is no doubt that milk contains large amounts of calcium. Many trials have been carried out over the past decade to compare the availability of calcium in milk with several other sources of calcium, such as salts, mineral waters, and plant products [26]. The studies on availability were carried out on men or women, using a variety of methods (fractional or apparent absorption, urinary calcium). None showed that the calcium in milk was more efficiently used than that from any other source. Carbonate, gluconate, citrate-malate (CCM), chloride, lactate, acetate, phosphate and citrate have all been tested [26]. Mineral waters containing calcium bicarbonate or sulfate were not any better $[4,5,56]$.

The growing pig is a useful experimental model in which changes in bone and mineral metabolism caused by diets with varying mineral content may be investigated $[8,31$, $37,39,45]$. Clearly, it is much more feasible to work with young growing animals, whose calcium metabolism is very active, than to attempt such studies on children.

Our previous studies in pigs have provided no evidence that calcium is better absorbed from milk and milk products (casein phosphopeptides, skim milk or yogurt) than from mineral salts $\left(\mathrm{CaCO}_{3}\right.$, $\mathrm{CCM}, \mathrm{CaHPO}_{4}$ ) incorporated in cereal + soya diets [35, 36, 38]. However, the breaking strength of bones from pigs fed yogurt as a calcium source is better than that of bones from pigs that obtained their calcium mostly from inorganic salts [38].
Long term clinical studies on bone have not yet been done using calcium-rich mineral waters. Hence, there is, as yet, no evidence showing that the calcium from mineral water (providing calcium as sulfate or bicarbonate) is as effective as calcium from carbonate or milk. While several human studies indicate that calcium from these sources is as well absorbed as that from milk or calcium carbonate $[5,7,56]$, only one study, that of Cepollaro et al. [4], reported a positive effect of consuming a high-calcium bicarbonate water on the bone density of 45 menopausal women, after 13 months of this form of supplementation. The control group (who drank a low-calcium water) was given no calcium supplement (calcium intake: supplemented, $1500 \mathrm{mg} \cdot$ day $^{-1}$; unsupplemented, $949 \mathrm{mg} \cdot \mathrm{day}^{-1}$ ). Apart from this trial, no data on the long-term effects of other high-calcium mineral waters on bone are available.

Only one study on rats found that increasing dietary calcium intake with calcium sulfate led to an increase in bone mineral content 4 weeks later. The same calcium intake from milk provided similar (ash as \% dry matter), or better mineralization ( $\mathrm{Ca}$ as a $\%$ of bone-dry matter) than calcium sulfate [41]. Lastly, milk and dairy products are not only excellent sources of calcium; they also provide an almost complete diet whose consumption provides a meal effect. This fosters the absorption of calcium and provides an intake of phosphorus that is essential for bone deposition [16]. Any other source of calcium, such as calcium supplements and mineral waters cannot provide these advantages. Thus, three calcium sources, milk$\mathrm{Ca}$, calcium sulfate (analogous to high 
Ca-sulfate mineral waters) and calcium carbonate (as a reference source) were compared by a combination of direct and indirect (bone-markers) bone measurements in growing pigs.

\section{MATERIALS AND METHODS}

\subsection{Animals and feeding}

Twenty-four 2 month-old male crossbred pigs (Cepra, Vermenton, France) weighing $19.6 \pm 0.4 \mathrm{~kg}$ were randomly assigned to one of three groups. Each of them was fed a diet in which one of the $3 \mathrm{Ca}$ sources provided more than $50 \%$ of the total intake. The dietary Ca levels were approximately one third lower than the normal Ca dietary allowances of growing pigs (at the start of the experiment) [15] to emphasize any difference in the availability of calcium from the 3 sources.

The diets were initially formulated to provide $0.6 \%$ total calcium, of which $70 \%$ $(0.42 \% \mathrm{Ca})$ was derived from milk ("milk" group), or from calcium sulfate ("sulfate" group), or from calcium carbonate (control "carbonate" group). The $0.42 \%$ Ca was obtained from milk by incorporating $29 \%$ skimmed milk powder into the diet, the basal ingredients provided $0.06 \% \mathrm{Ca}$ and the $0.6 \%$ total $\mathrm{Ca}$ was reached by adding $0.372 \% \mathrm{Ca}$ carbonate (providing $0.14 \% \mathrm{Ca}$ ). The $0.42 \%$ $\mathrm{Ca}$ for the calcium sulfate diet would have been obtained by incorporating $1.6 \% \mathrm{Ca}$ $\mathrm{SO}_{4}$. Since pigs fed such a "sulfate" diet suffered from diarrhea in a preliminary assay, the percent of Ca sulfate utilized was 1.23 (providing $0.33 \% \mathrm{Ca}$ ), basal ingredients provided $0.14 \% \mathrm{Ca}$ and $0.44 \%$ calcium carbonate was added. The average Ca provided as sulfate was $50 \%$ of the total calcium in the "sulfate" group. The control diet contained $0.13 \%$ Ca provided by basal ingredients and $0.51 \%$ by calcium carbonate.

Milk, sulfate and control diets were not identical, but they were equivalent in terms of energy [14.8 (or 10.6) MJ digestible (or net) energy $\cdot \mathrm{kg}^{-1}$ diet], protein, crude fibers, fat, vitamins and minerals. They were also equivalent in terms of phosphorus contents including phytic P: 2 (carbonate), 1.7 (milk) and 2 (sulfate diet) $\mathrm{g} \cdot \mathrm{kg}^{-1}$ (estimated according to [34]). Moreover, the three diets contained similar amounts of wheat ( $\geq 42 \%)$, a phytase-rich cereal which optimizes the plant phosphorus utilization by hydrolyzing phytates [34]. These diets (Tab. I) were formulated to meet the French recommendations for nutrient supply to growing pigs (except for $\mathrm{Ca}$ ) [19]. The digestible amino acids and energy contents (including starch and soluble carbohydrates) of the three diets were carefully equalized using recent data obtained in pigs [20, 32, 47].

All the pigs were pair-fed. The pigs were housed individually (pens of $1 \times 2.5 \mathrm{~m}$, concrete floor and walls), and their growth was evaluated weekly for a total of 75 days. The animals were stunned by electronarcosis and killed by exsanguination. The study complied with the French regulations governing animal care $\left(\mathrm{n}^{\circ} 88-123,1988 ; \mathrm{n}^{\circ} 87-848\right.$, 1987).

\subsection{Plasma parameters}

Venous blood samples were monitored for calcium, inorganic $P$, total and bone alkaline phosphatase (ALP) isoenzyme activity, osteocalcin, 1,25-dihydroxycholecalciferol (calcitriol), immunoreactive parathyroid hormone (iPTH), carboxy-terminal propeptide of type I procollagen (PICP), and the carboxy-terminal cross-linked telopeptide of type I collagen (ICTP). The samples were collected from the anterior vena cava, 1 month before slaughter (day 45), or at slaughter during exsanguination.

$\mathrm{Ca}$, inorganic phosphorus, $\mathrm{PTH}$, calcitriol, ICTP and PICP were determined at slaughter only. Total and bone ALP (EC 3131), and osteocalcin were determined twice, at slaughter and one month before. Plasma ALP and osteocalcin were used as markers of osteoblast activity [6]. The plasma concentration of PICP was 
considered to be a marker of the synthesis of bone collagen and ICTP as a marker of its breakdown [9]. ICTP is the carboxy-terminal telopeptide region of type I collagen, cross-linked via pyridinoline cross-links; it is liberated during the degradation of type I collagen, the only collagen type found in mineralized bone [43]. Plasma $\mathrm{Ca}$, inorganic

Table I. Diet composition.

\begin{tabular}{|c|c|c|c|}
\hline Diets & Carbonate & Milk & Sulfate \\
\hline \multicolumn{4}{|l|}{ Ingredient $^{(1)}, \%$} \\
\hline Wheat & 42.00 & 42.50 & 42.00 \\
\hline Barley & 18.38 & 24.67 & 17.65 \\
\hline Soybean meal 48 & 13.50 & - & 13.70 \\
\hline Fish soluble & 6.00 & - & 6.00 \\
\hline Skim milk powder & - & 29.00 & - \\
\hline Saccharose & 14.00 & - & 14.00 \\
\hline Maize oil & 3.26 & 3.00 & 3.42 \\
\hline Ca carbonate & 1.33 & 0.372 & 0.472 \\
\hline Ca sulfate & - & - & 1.23 \\
\hline Mono Na phosphate & 1.05 & - & 1.06 \\
\hline Mineral and vitamin $\operatorname{mix}^{(2)}$ & 0.10 & 0.10 & 0.10 \\
\hline L-lysine-HCl & 0.231 & - & 0.228 \\
\hline DL-methionine & 0.045 & 0.040 & 0.045 \\
\hline L-threonine & 0.085 & 0.065 & 0.085 \\
\hline L-tryptophan & 0.013 & - & 0.013 \\
\hline $\mathrm{NaCl}$ & - & 0.25 & - \\
\hline \multicolumn{4}{|l|}{ Nutrients, \% } \\
\hline \multicolumn{4}{|l|}{ Mineral contents (analyzed) } \\
\hline Calcium & 0.64 & 0.62 & 0.65 \\
\hline Phosphorus & 0.53 & 0.54 & 0.52 \\
\hline \multicolumn{4}{|l|}{ Calculated data ${ }^{(3)}$} \\
\hline Phytic P & 0.20 & 0.17 & 0.20 \\
\hline Starch & 33.34 & 36.40 & 32.96 \\
\hline Soluble carbohydrates & 16.80 & 16.78 & 16.80 \\
\hline Fat & 5.42 & 4.56 & 5.57 \\
\hline Crude fiber & 2.44 & 2.10 & 2.42 \\
\hline Neutral detergent fiber & 8.83 & 8.15 & 8.74 \\
\hline Proteins & 18.46 & 18.60 & 18.46 \\
\hline Digestible lysine & 1.021 & 1.022 & 1.021 \\
\hline Digestible methionine & 0.378 & 0.350 & 0.350 \\
\hline Digestible sulfur amino acids & 0.614 & 0.614 & 0.613 \\
\hline Digestible threonine & 0.664 & 0.664 & 0.664 \\
\hline Digestible tryptophan & 0.210 & 0.189 & 0.189 \\
\hline Digestible energy, $\mathrm{MJ} \cdot \mathrm{kg}^{-1}$ & 14.82 & 14.79 & 14.81 \\
\hline
\end{tabular}

(1) Wheat, barley and soybean meal 48 (i.e. $48 \%$ protein) from Bonaliment, Limours. Fish soluble: solubilized fish protein concentrate (CPSP 90) from Sopropêche, Boulogne-sur-Mer. Skim milk powder from Sofivo, Condé-surVire. Added aminoacids from Rhône-Poulenc, Antony. Calcium carbonate, sodium chloride and monosodium phosphate from Prolabo, Bondoufle and calcium sulfate $\left(\mathrm{CaSO}_{4}, 1 / 2 \mathrm{H}_{2} 0 ; 26.5 \% \mathrm{Ca}\right)$ from Merck-France, Nogent-surMarne, France.

(2) Trace elements and vitamin mixtures adapted from [8].

(3) According to [19, 20, 32, 34]. 
$\mathrm{P}$, total and bone ALP were measured as previously described [39, 40]. PICP was determined by radioimmunoassay (Orion Diagnostica, Espoo, Finland). The lowest detectable concentration was $1.2 \mu \mathrm{g} \cdot \mathrm{L}^{-1}$ and the intra- and inter-assay coefficients of variation were $3 \%$ and $5 \%$, respectively. ICTP was determined by radioimmunoassay (Orion Diagnostica, Espoo, Finland). The lowest detectable concentration was $0.5 \mu \mathrm{g} \cdot \mathrm{L}^{-1}$ and the intra- and inter-assay coefficients of variation were both near $5 \%$. A modified radioimmunoassay kit (OstkPr, Oris, Gif- sur-Yvette, France) was used to determine osteocalcin, with purified bovine osteocalcin as the standard and tracer, rabbit antiserum to bovine osteocalcin, and an internal porcine standard [39]. Calcitriol was measured by a radioreceptor assay using a kit (Nichols Institute Diagnostics, San Juan Capistrano, USA) after extraction on modified $\mathrm{C}_{18} \mathrm{OH}$ columns. Immunoreactive PTH was measured by a two-site immunoradiometric assay (Allegro intact PTH kit, Nichols Institute, Mallinckrodt Diagnostica, Evry-Lisses, France) [8]. The sensitivity of the method was $0.1 \mathrm{pmol} \cdot \mathrm{L}^{-1}$. The intraand inter-assay coefficients of variation were $3.4 \%$ and $5.6 \%$, respectively.

\subsection{Urinary parameters}

A sample of 15 pigs ( 5 per group) were kept in individual cages and fed the same amounts of feed $\left(1.8 \pm 0.0 \mathrm{~kg} \cdot \mathrm{day}^{-1}\right)$ for the last 10 days immediately before slaughter. A $5 \%$ sample of each $24 \mathrm{~h}$ urine collection was taken and the samples were pooled for the 10 days. Calcium and deoxypyridinoline were determined on these urine samples [40]. The concentration of deoxypyridinoline was measured using a competitive enzyme immunoassay (PYRILINKS-D, Metra Biosystems from Behring Diagnostic, Rueil-Malmaison, France). This metabolite is a crosslink found mainly in the type I collagen of bone and released in the process of bone degradation. It is thus a marker of bone resorption [6].

\subsection{Bone parameters}

Bone density, breaking strength and ash contents were assessed on a total of 9 bones collected at slaughter and dissected free of soft tissues: 1 tibia (right), the first 2 lumbar vertebras (L1 and L2), 4 main (finger III, internal and IV, external) metatarsals (right and left hind-legs) and 2 main (finger III and IV) metacarpals (left foreleg).

\subsubsection{Bending moments}

The "three-point bending test" at fracture was used to determine the bending moment on the tibia and the 6 metatarsal and metacarpal bones [8]. The failure load, the force (Newtons [N]) applied to the midpoint of the bone until breaking, was determined with a universal testing machine (AP 4000 Erichsen, Villetaneuse, France). The bending moment was calculated according to the formula: bending moment $=\mathrm{F} \times \mathrm{L} / 4$, where $\mathrm{F}$ is the failure load, and L the length (m) between the two fulcrum points supporting the bone. It is expressed in $\mathrm{N} \times \mathrm{m}$. This parameter was selected because of its great sensitivity to mineral nutrition in the pig $[8,35,38,39]$.

\subsubsection{Ash contents}

External, left and right, metarsal and left internal metacarpal bones were used to determine the volume (external metatarsals only), dry matter and ash contents [39]. Ash ( $g \cdot 100 \mathrm{~g}^{-1}$ dry matter) was evaluated for the whole bone, the diaphyses (to represent cortical bone), and the proximal and distal epiphyses (to represent spongy bone). Values for ash relative to apparent whole bone volume were calculated for the two external, left and right, metatarsals.

\subsubsection{Bone mineral density}

Bone mineral density (BMD), in grams per square centimeter, and bone mineral contents (BMC), in grams, were measured 
using dual-energy X-ray absorptiometry (DEXA) with a Hologic QDR-1000 X-ray bone densitometer (Hologic France, Massy, France). BMD was measured in the whole bone and in three regions of the tibia and 2 metatarsal (left, internal and external) bones: 2 corresponding to the distal and proximal epiphyses which are rich in cancellous bone and one to the mid-diaphysis which consists of cortical bone. Total BMD was also determined on the 2 vertebrae. Lastly, the total ash content, obtained by mineralization of the whole bone, and the bone mineral content (BMC), evaluated by densitometry, of the external left metatarsal were compared.

\subsection{Statistical methods}

The data were analyzed using a statistical software (SuperANOVA, Abacus Concepts Berkeley, CA). Growth parameters, plasma minerals and hormones, ICTP and PICP, urinary bone-related markers were analyzed by one-way (diet) analysis of variance (ANOVA) and Newman-Keuls multiple mean comparison (MMC) as a post test [50]. Bone ash contents, densitometry and bending moments were analyzed by two-way (diet and bone) ANOVA and MMC. Plasma ALP, osteocalcin were analyzed by twoway (diet and time) ANOVA and MMC. Relationships between plasma and/or bone variables were assessed by linear correlation [50] with all individual data obtained at slaughter.

\section{RESULTS}

\subsection{Performance}

The performances of the 3 groups were similar. The body weights $(\mathrm{kg})$ at slaughter did not differ: $71 \pm 0.8$ (carbonate), $73 \pm$ 2 (milk) and $72 \pm 1.3$ (sulfate), nor did the average daily weight gains, $0.69,0.71$ and $0.69( \pm 0.02) \mathrm{kg} \cdot \mathrm{day}^{-1}$, nor the feed-effi- ciency ratios ( $\mathrm{kg}$ body weight gain $\cdot \mathrm{kg}^{-1}$ diet consumed), 0.47, 0.49 and 0.47 ( \pm 0.01 ). The total amount of calcium $(\mathrm{g})$ consumed by each of the 3 groups during the whole experiment did not differ: $675 \pm 14$ (carbonate), $671 \pm 7$ (milk) and $699 \pm 5$ (sulfate).

\subsection{Plasma minerals, calciotropic hormones and bone-related markers (Tab. II)}

The diets had no effect on the plasma concentrations of minerals, calcitriol, iPTH, osteocalcin, or on the urinary or plasma markers of bone collagen synthesis (plasma PICP), or degradation (plasma ICTP and urinary deoxypyridinoline). The plasma concentrations of total and bone-specific alkaline phosphatase were greater $(P<0.05)$ in the milk group than in the two others, and these two parameters were highly correlated ( $r=0.77$, at 45 days and $r=0.71$ at slaughter, $P<0.01)$. The urinary $\mathrm{Ca}$ excretion did not differ in the 3 groups.

\subsection{Bone parameters}

The fresh weights of the bones $(\mathrm{g})$ for the 3 groups of pigs were similar: $21.5 \pm$ 0.8 (carbonate), $23 \pm 1$ (milk) and $22.6 \pm$ 1 (sulfate); average of 4 bones ( 3 metatarsal and 1 metacarpal bones).

The ash contents of the metacarpal and metatarsal bones (Tab. III) from the pigs fed the milk diet were generally greater than those fed the two other diets. This was significant $(P<0.01)$ for ash \% dry matter in the spongy and whole bone, for total bone ash content and for ash/unit volume. This effect was less marked in the cortical bone, for which the difference between milk and carbonate values was not significant.

Bone bending moments (Tab. IV) in the milk group were also greater than those in the 2 other groups. This was significant for the overall metacarpal mean, for each pair (right and left) mean of metatarsals, for the 
Table II. Plasma concentrations of minerals and calcium-regulating hormones, and plasma or urinary concentrations of bone markers ${ }^{(1)}$.

\begin{tabular}{|c|c|c|c|c|c|}
\hline Diet & Carbonate & Milk & Sulfate & Pooled SI & et effect $(P)$ \\
\hline Plasma minerals and hormo & & & & & \\
\hline Calcium, $\mathrm{mmol} \cdot \mathrm{L}^{-1}$ & 2.57 & 2.67 & 2.60 & 0.05 & NS \\
\hline Phosphate, $\mathrm{mmol} \cdot \mathrm{L}^{-1}$ & 2.16 & 2.10 & 2.29 & 0.05 & NS \\
\hline $\mathrm{PTH}, \mathrm{pmol} \cdot \mathrm{L}^{-1}$ & 0.51 & 0.60 & 0.79 & 0.13 & NS \\
\hline Calcitriol, $\mathrm{pmol} \cdot \mathrm{L}^{-1}$ & 173 & 161 & 185 & 12 & NS \\
\hline Plasma bone-markers & & & & & \\
\hline $\begin{array}{l}\text { Alkaline phosphatase } \\
\text { total IU.L } \mathrm{L}^{-1}\end{array}$ & & & & & \\
\hline day 45 & 67 & 88 & 57 & & \\
\hline slaughter & 91 & 107 & 77 & & \\
\hline average $^{(2)}$ & $79^{b}$ & $97^{\mathrm{a}}$ & $68^{\mathrm{b}}$ & 7.3 & 0.001 \\
\hline bone isoenzyme, $\mathrm{U} \cdot \mathrm{L}^{-1}$ & & & & & \\
\hline day 45 & 75 & 102 & 75 & & \\
\hline slaughter & 72 & 92 & 65 & & \\
\hline average $^{(2)}$ & $74^{\mathrm{b}}$ & $97^{\mathrm{a}}$ & $70^{\mathrm{b}}$ & 10 & 0.014 \\
\hline Osteocalcin, $\mathrm{ng} \cdot \mathrm{mL}^{-1}$ & & & & & \\
\hline day 45 & 257 & 191 & 229 & & \\
\hline slaughter & 285 & 209 & 251 & & \\
\hline average $^{(2)}$ & 271 & 200 & 240 & 29 & NS \\
\hline PICP, $\mu \mathrm{g} \cdot \mathrm{L}^{-1}$ & 6.3 & 6.1 & 6.1 & 0.1 & NS \\
\hline $\mathrm{ICTP}, \mu \mathrm{g} \cdot \mathrm{L}^{-1}$ & 11.4 & 11.7 & 12.2 & 0.9 & NS \\
\hline Urinary parameters, per mm & creatinine & & & & \\
\hline Deoxypyridinoline, $\mathrm{nmol}$ & 11.4 & 11.6 & 10.9 & 1.4 & NS \\
\hline calcium, mmol & 0.10 & 0.18 & 0.20 & 0.03 & NS \\
\hline
\end{tabular}

(1) Values at slaughter, except for alkaline phosphatase and osteocalcin; one way (diet) ANOVA except for alkaline phosphatase and osteocalcin ${ }^{(2)}$.

(2) Two-way, diet and time, ANOVA, significant time-effect (slaughter $>$ day 45, $P<0.05$ ) for plasma total alkaline phosphatase only; $\mathrm{a}>\mathrm{b}, P<0.05$, multiple mean comparison post-ANOVA.

PTH: immunoreactive parathyroid hormone, PICP: type I procollagen C-terminal propeptide, ICTP : type I collagen C-terminal cross-linked telopeptide.

overall mean from the 4 metatarsals and, for the overall metacarpal + metatarsal mean. There was no significant difference between the 3 groups for the tibia values.

Bone densitometry (Tab. V). The BMD of the milk-fed pigs was greater than that of bones of pigs on the two other diets. This was significant $(P<0.01$ or $P<0.05)$ for the total BMD of each of the 5 bones tested, and for the BMD of each cancellar bone area of the 3 bones tested. Again, this effect was less marked or even absent for the cor- tical bone samples from the tibia or the internal metatarsals. The whole BMD of the left external metatarsals was highly and significantly $(P<0.01)$ correlated with the other bone parameters, such as whole bone ash $(r=0.87)$, ash \% dry matter of the whole bone $(r=0.63)$, ash relative to bone volume $(r=0.71)$, apparent bone density (ratio fresh weight without medulla/whole apparent volume measured according to Archimede's principle, $r=0.63$ ) and, spongy BMD with ash \% dry matter of the spongy 
Table III. Ash contents of the metatarsal and metacarpal bones.

\begin{tabular}{lrrrrr}
\hline Diet & Carbonate & Milk & Sulfate & Pooled SEM & Diet effect (P) \\
\hline Total ash per bone ${ }^{(1)}, \mathrm{g}$ & $5.1 \mathrm{~B}$ & $6.1 \mathrm{~A}$ & $5.5 \mathrm{~B}$ & 0.2 & 0.0001 \\
$\begin{array}{l}\text { Ash \% bone dry matter } \\
\quad \text { Spongy bone }\end{array}$ & & & & & \\
$\quad$ Cortical bone & $52.6 \mathrm{~B}$ & $38.9 \mathrm{~A}$ & $37.2 \mathrm{~B}$ & 0.8 & 0.001 \\
$\quad$ Whole bone & $53.6 \mathrm{a}$ & $51.5 \mathrm{~b}$ & 1.1 & 0.04 \\
Ash/volume, g.100 $\mathrm{cm}^{-3(2)}$ & $27.1 \mathrm{~B}$ & $30.4 \mathrm{~A}$ & $27.4 \mathrm{~B}$ & 0.8 & 0.0001 \\
& & & & & \\
Bone mineral content, $\mathrm{g}^{(3)}$ & & & & & \\
$\quad$ densitometry & $5.8 \mathrm{a}$ & $6.9 \mathrm{~b}$ & $6.2 \mathrm{a}$ & 0.2 & 0.003 \\
$\quad$ mineralization & $5.3 \mathrm{a}$ & $6.4 \mathrm{~b}$ & $5.7 \mathrm{a}$ & 0.2 & 0.002 \\
\hline
\end{tabular}

(1) Average of 3 bones: external, left and right, metatarsals + left internal metacarpal, $P$ value for two-way, bone and diet, ANOVA.

(2) Average of 2 bones: external, right and left, metarsals, $P$ value for two-way, bone and diet, ANOVA.

(3) Values obtained either by densitometry (BMC, g) or mineralization (ash, g) on the same bone: external left metatarsals correlation between both measures: $\mathrm{y}(\mathrm{ash}, \mathrm{g})=0.953 \times(\mathrm{BMC}, \mathrm{g})-0.217 ; r=0.995, P<0.001$.

Means with no letters in common differ; lower case, $P<0.05$; upper case, $P<0.01$; multiple mean comparison post-ANOVA.

No significant bone $\times$ diet interaction except for cortical bone, $P=0.014$.

Table IV. Bending moments $(\mathrm{N} \times \mathrm{m})$ of the metacarpal and metatarsal bones.

\begin{tabular}{|c|c|c|c|c|c|}
\hline Diet & Carbonate & Milk & Sulfate & Pooled SEM & Diet effect (P) \\
\hline \multicolumn{6}{|l|}{ Left metacarpals ${ }^{(1)}$} \\
\hline Internal & 6.5 & 7.5 & 6.5 & \multirow{2}{*}{0.4} & \multirow{2}{*}{0.10} \\
\hline External & 4.6 & 5.2 & 4.7 & & \\
\hline \multicolumn{6}{|l|}{ Metatarsals } \\
\hline \multicolumn{6}{|l|}{$\operatorname{Right}^{(1)}$} \\
\hline Internal & 4.8 & 5.5 & 5.1 & \multirow{2}{*}{0.3} & \multirow{2}{*}{0.013} \\
\hline External & $4.7 \mathrm{a}$ & $5.7 b$ & $4.9 \mathrm{a}$ & & \\
\hline \multicolumn{6}{|l|}{$\operatorname{Left}^{(1)}$} \\
\hline Internal & 4.9 & 5.8 & 4.8 & \multirow{2}{*}{0.3} & \multirow{2}{*}{0.015} \\
\hline External & 4.7 & 5.7 & 4.7 & & \\
\hline Overall metatarsal mean ${ }^{(2)}$ & $4.8 \mathrm{~B}$ & $5.7 \mathrm{~A}$ & 4.9B & 0.3 & 0.001 \\
\hline \multicolumn{6}{|l|}{ Overall, metatarsals + } \\
\hline Right tibia & 39.7 & 44.7 & 44.3 & 2.3 & NS \\
\hline
\end{tabular}

(1) Two-way, diet and bone (internal/external), ANOVA.

(2) Two-way, diet and bone ( 4 bones per diet), ANOVA.

(3) Two-way, diet and bone, ANOVA; 6 bones per diet: internal and external, left metacarpals and, left and right metatarsals, overall bone effect: internal metacarpals $>$ all other bones $(P<0.01)$.

Means with no letters in common differ; lower case, $P<0.05$, upper case, $P<0.01$, multiple mean comparison post-ANOVA.

No significant treatment $\times$ bone interaction whatever the group of bones. 
Table V. Bone mineral density (BMD) $\left(\mathrm{g} \cdot \mathrm{cm}^{-2}\right)$ of tibia, metatarsals and vertaebrae. Measures on whole bones and on cortical and spongy subregions.

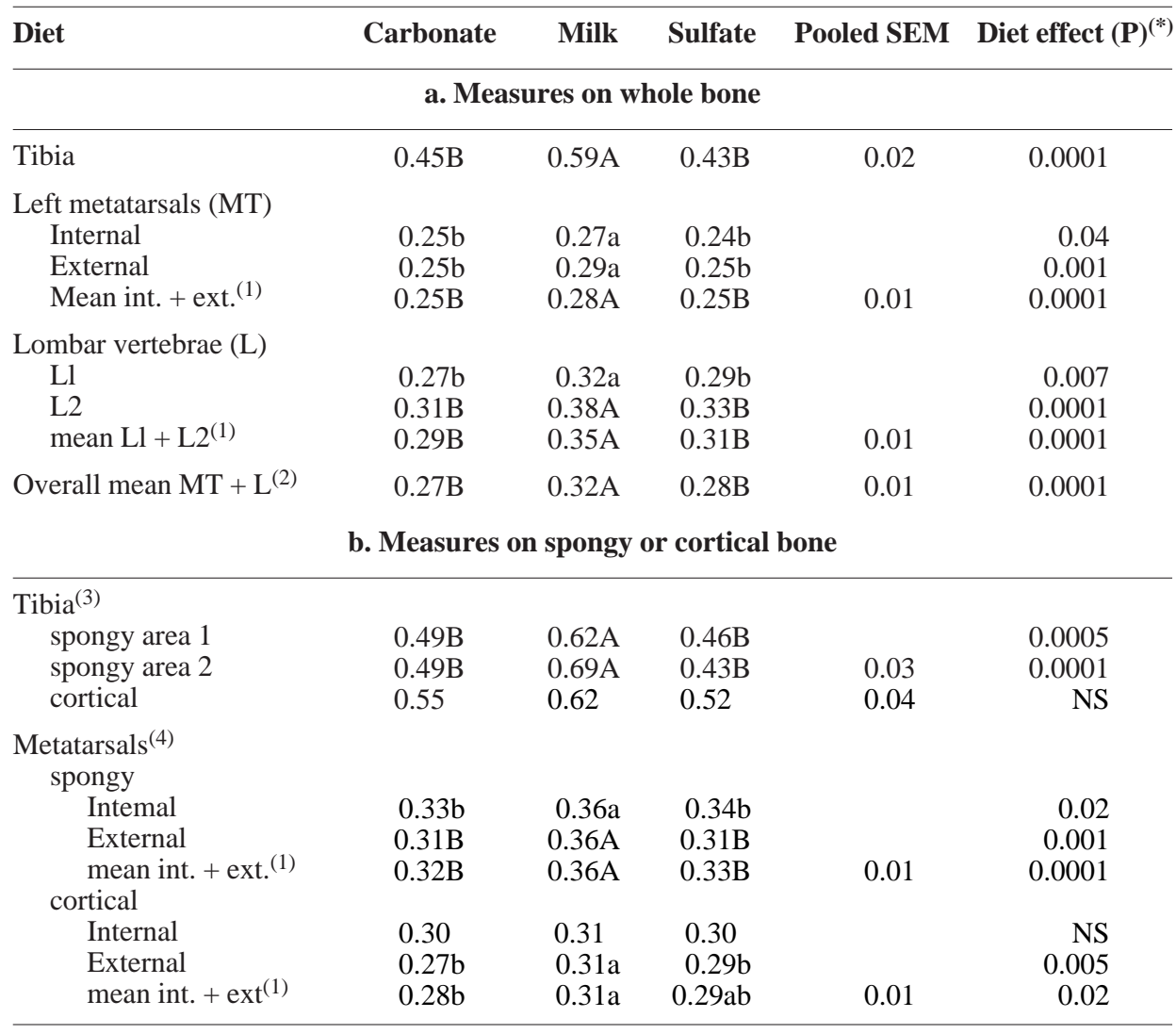

(*) $P$ value for one-way (diet) or two-way (diet and bone) ANOVA.

(1) Two-way, diet and bone (external/internal or L1/L2), ANOVA.

(2) Two way, diet and bone ( 4 bones) ANOVA.

Significant overall bone effect $(P<0.0001)$ with L2 $>$ L1 $>$ MT (int. or ext.), post-ANOVA multiple mean comparison $(P<0.01)$.

${ }^{(3)}$ Left tibia, spongy area 1 and 2: distal and proximal epiphysis respectively, cortical bone: diaphysis.

(4) Left metatarsals, spongy bone: mean value for distal and proximal epiphysis, cortical bone: diaphysis.

Means with no letters in common differ; lower case, $P<0.01$; upper case, $P<0.05$, post-ANOVA multiple mean comparison.

No bone $\times$ treatment interaction whatever the row.

bone $(r=0.78)$ and cortical BMD with bending moment $(r=0.68)$. There were high $(r \geq 0.8)$, significant $(P<0.01)$ correlations between the overall bone mineral contents obtained by densitometry (BMC) and those obtained after mineralization (ash content) (Tab. III, for the left external metatarsal, $r=0.995)$.

\section{DISCUSSION}

The results clearly indicate that the diet in which the calcium was mainly provided by the skimmed milk powder led to bones with a greater mineral content, breaking strength and density. These bone changes cannot be due to better growth, since the growth 
performance of the pigs and the bone weights were not affected by the diets. Consequently, the bone changes in the "milk" group must be due to less resorption or to greater bone formation, or a combination of the two, resulting in better mineralization. The plasma ICTP, urinary deoxypyridinoline (parameters reflecting bone collagen degradation) and PTH levels for the three dietary groups were similar. Modification of bone resorption can therefore be ruled out. The plasma PICP concentrations for the three groups were also similar, indicating that the synthesis of the bone matrix was not modified. But the circulating levels of bone and total ALP were elevated in the milk-fed pigs. This increase in markers of bone calcification [1] and bone mineral content suggest that the mineralization was modified. Hence, the calcium from the "milk diet" was more available to the pigs than was the calcium in the two other diets.

The studies carried out to date in humans have failed to demonstrate that milk calcium is more efficiently absorbed than calcium from carbonate $[17,27,30,42,48$, 49], or calcium from mineral waters, bicarbonate or sulfate $[5,7,56]$. Similarly, longterm studies in growing pigs [36-38] have provided no evidence that the calcium in milk and milk products (casein phosphopeptides, skim milk or yogurt) is better absorbed than is calcium from mineral salts.

However, pigs fed yogurt as a calcium source have greater bone mineralization (evaluated by breaking strength) than pigs receiving inorganic calcium sources $\left(\mathrm{CaHPO}_{4}+\mathrm{CaCO}_{3}\right)$ [35]. Partridge [33] has also shown greater calcium absorption in very young pigs fed milk than in those fed an isocalcium diet containing soybean meal. Similar results have been obtained in piglets by Matsui et al. [29].

There is also evidence that dietary factors present in milk, such as casein phosphopeptides and lactose, enhance mineral retention. Milk casein phosphopeptides have been shown to have a positive effect on the absorption of calcium, in vivo and in vitro in rats with an increase in the intestinal transfer of calcium and, on bone metabolism [12, $21,23,28,46,51,55]$. Other in vivo studies on rats have demonstrated that lactose stimulates calcium absorption or retention by acting directly on the intestine, and on the bone $[3,11,13,25,44]$. There is also indirect in vitro evidence of the effect of lactose on calcium absorption from studies with isolated intestinal loops $[2,10]$, where lactose was compared to another sugar and to a control without lactose [2]. Calcium is better absorbed by unweaned human babies fed normal mother's milk than when fed mother's milk from which the lactose has been removed [22].

Another potential benefit of milk as a source of calcium is its phosphorus content. The simultaneous presence of calcium and phosphorus may create favorable conditions to enhance bone mineral deposition, as demonstrated in pigs [37, 39]. Ingesting milk may also be considered to be a meal, which itself enhances calcium absorption [17]. It is therefore surprising that some of the studies on pigs and all those done on humans have failed to demonstrate that calcium from milk is more available than the calcium from inorganic sources.

The calcium provided by the diets in the present experiment represented only $70 \%$ of the French recommended dietary allowance for pigs of that age [15]. Furthermore, our young pigs grew very rapidly $\left(0.7 \mathrm{~kg} \cdot \mathrm{day}^{-1}\right)$, and so must have used the minerals efficiently to build bones. Under these conditions of restricted intake and increased demand, which occurs frequently in young adolescents, the "milk" diet has ensured a better utilization of calcium (and phosphorus) than the two other diets in our pig study. Therefore, some milk components may have facilitated calcium absorption, allowing better bone mineralization. This effect was not observed previously when the calcium intake was not restricted $[35,38]$. 
The three groups of pigs grew identically, although the protein and energy components of the three diets were not the same. This is different from the results obtained for pigs fed milk or yogurt and pigs fed soybean protein based diets [33, 38, 52, 53]. The milk and yogurt diets provided better growth, possibly because of better utilization of milk proteins. The discrepancy may be due to the careful equalization of the digestible amino acid and energy contents of the three diets. This adjustment was based on recent data [20, 32, 47], but such adjustments cannot be done in human trials. It is also difficult to control the calcium intake, the age of the subjects and the compositions of the calcium-containing diets (energy, proteins, fiber and so on). All these factors influence calcium absorption and bone metabolism, so that any one of them may mask the greater availability of calcium from milk compared to calcium from calcium salts.

The lower calcium availability of the sulfate and carbonate diets might also be confounded with the presence of soybean meal, a phytate-rich product, instead of milk. Soybean may decrease calcium absorption as shown in humans [18] and pigs [29, 33]. However, this did not interfere in our pigs. Firstly, the three diets were formulated to provide very similar levels of phytates. Secondly, we used phytase-rich cereals (namely wheat and barley) especially to enhance phytate hydrolysis, thus reducing the risks of calcium-phytate formation [34]. In fact, we have reported almost identical calcium absorptions in pigs fed normocalcic diets containing either wheat + soybean or wheat + milk-derived products $[35,38]$. Thirdly, the soybean meal was incorporated at a moderate concentration (less than half the milk \%) and was not the unique source of protein in the sulfate and carbonate diets, which also contained fish soluble (Tab. I).

The pigs fed the $\mathrm{CaSO}_{4}$-diet used their calcium to build bone as efficiently as did those on the $\mathrm{CaCO}_{3}$-diet in the present experiment. There was also no increase in urinary calcium in the pigs fed $\mathrm{CaSO}_{4}$. But, sulfates are believed to increase urinary calcium in humans [24, 54], and this could prevent the incorporation of calcium into bone, as demonstrated in sheep [14]. Calciuria was not significantly elevated by $\mathrm{CaSO}_{4}$ rich mineral waters in short-term $(36 \mathrm{~h})$ studies on humans [5]. But calciuria plays a much smaller role in $\mathrm{Ca}$ excretion (around $1 \%$ of ingested calcium in the present and previous experiences $[37,39]$ ) in pigs than it does in humans, where urinary calcium excretion is the most important component of the calcium balance. These differences in the metabolism of calcium between the two species emphasize the caution required in extrapolating our results to humans.

In summary, our data suggest that the calcium provided by milk is more efficiently used to build bones by growing subjects with a restricted calcium intake than is the calcium provided as sulfate or carbonate salts.

\section{ACKNOWLEDGMENTS}

We thank V.L. Defretin, A. Ayerbe for advice and assistance, X. Blanc (UPAE, INRA, Jouyen-Josas, France) and J.-C. Bernardin and D. Besnard for technical support and, Myriam Defrance for secretarial help. The English text was edited by O. Parkes. This work was supported by a grant from Arilait-Recherches (Paris)

\section{REFERENCES}

[1] Alkaline phosphatase: physiological functions, in: McComb R.B., Bowers G.N., Posen S. (Eds.), Alkaline phosphatase, Plenum Press, New York, USA, 1979, pp. 865-902.

[2] Armbrecht H.J., Age and the effects of lactose on calcium and phosphorus uptake by rat small intestine, Nutr. Res. 7 (1987) 1169-1177.

[3] Buchowski M.S., Miller D.D., Lactose, calcium source and age affect calcium bioavailability in rats, J. Nutr. 121 (1991) 1746-1750.

[4] Cepollaro C., Orlandi G., Ferruci G., Arditti J.C. Toti E., Gennari C., Effect of calcium supplementation as a high-calcium mineral water on bone loss in postmenopausal women, Calcif. Tissue Int. 59 (1996) 238-239. 
[5] Couzy F., Kastenmayer P., Clough J., MunozBox R., Barclay D.V., Calcium bioavailability from calcium- and sulfate-rich mineral water, compared with milk, in young adult women, Am. J. Clin. Nutr. 62 (1995) 1239-1244.

[6] Delmas P., Garnero P., Utility of biochemica markers of bone turnover, in: Marcus R., Feldman D., Kelsey J. (Eds.), Osteoporosis, Acad Press, New York, USA, 1996, pp. 1075-1088.

[7] Dokkum van W., De la Guéronnière V. Schaafsma G., Bouley C., Luten J., Latgé C., Bioavailability of calcium of fresh cheeses, enteral food and mineral water. A study with stable calcium isotopes in young adult women, Br. J. Nutr. 75 (1996) 893-903.

[8] Eklou-Kalonji E., Zérath E., Colin C., Lacroix C., Holy X., Denis I., Pointillart A., Calcium-regulating hormones, bone mineral content, breaking load and trabecular remodeling are altered in growing pigs fed calcium-deficient diets, J. Nutr. 129 (1999) 188-193.

[9] Eriksen E.F., Charles P., Melsen F., Mosekilde L., Risteli L., Risteli J., Serum markers of type I collagen formation and degradation in metabolic bone disease: correlation with bone histomorphometry, J. Bone Miner. Res. 8 (1993) 127-132.

[10] Favus M.J., Angeid-Backman E., Effects of lactose on calcium absorption and secretion by rat ileum, Am. J. Physiol. 246 (1984) G281-G285

[11] Fournier P., Dupuis Y., Epaississement généralisé du squelette sous l'effet de l'administration continuelle de lactose, C.R. Acad. Sci. 285 (1964) 3090-3093.

[12] Gerber H.W., Jost R., Casein phosphopeptides: their effect on calcification of in vitro cultured embryonic rat bone, Calcif. Tissue Int. 38 (1986) 350-357.

[13] Greger J.L., Gutkowski C.M., Khazen R.R., Interaction of lactose with calcium, magnesium and zinc in rats, J. Nutr. 119 (1989) 1961-1967.

[14] Guéguen L., Besançon P., Influence des sulfates sur le métabolisme phosphocalcique: I. Utilisation du sulfate de calcium par le mouton, Ann. Biol. Anim. Bioch. Biophys. 12 (1972) 589-598.

[15] Guéguen L., Perez J.M., A re-evaluation of recommended dietary allowances of calcium and phosphorus for pigs, Proc. Nutr. Soc. 40 (1981) 373-378.

[16] Heaney R.P., Calcium, in: Belizikian J.P. Raiz G.A., Rodan G.A. (Eds.), Principles of bone biology, Acad. Press, New-York, USA, 1996, pp. 1007-1018.

[17] Heaney R.P., Smith K.T., Recker R.R., Hinders S.M., Meal effects on calcium absorption, Am. J. Clin. Nutr. 49 (1989) 372-376.

[18] Heaney R.P., Weaver C.M., Fitzsimmons M.L., Soybean phytate content: effect on calcium absorption, Am. J. Clin. Nutr. 53 (1991) 745-747.
[19] INRA, Recommandations alimentaires et Tables de composition, in: L'alimentation des animaux monogastriques : Porc, Lapin, Volailles, INRA (éd. et pub.) $2^{\mathrm{e}}$ éd., Paris, 1989, pp. 49-76 et 161-239.

[20] Jondreville C., Van den Broecke J., Gatel F., Van Cauvenberghe S., Ileal digestibility in feedstuffs for pigs, in: ITCF and Eurolysine (Eds.), ITCF, Paris, France, 1995, 53 pp.

[21] Kitts D.D., Yuan Y.V., Nagasawa T., Moriyama Y., Effect of casein, casein phosphopeptides and calcium intake on ileal ${ }^{45} \mathrm{Ca}$ disappearance and temporal systolic blood pressure in spontaneously hypertensive rats, $\mathrm{Br}$. J. Nutr. 68 (1992) 765-781.

[22] Kobayashi A., Kawai S., Obe Y., Nagashima Y., Effects of dietary lactose and a lactase preparation on the intestinal absorption of calcium and magnesium in normal infants, Am. J. Clin. Nutr. 28 (1975) 681-684.

[23] Lee Y.S., Noguchi T., Naito H., An enhanced intestinal absorption of calcium in the rat directly attributed to dietary casein, Agric. Biol. Chem. 47 (1979) 2009-2011.

[24] Lemann J. Jr., Urinary excretion of calcium, magnesium and phosphorus, in: Favus M.J. (Ed.), Primer on the metabolic bone diseases and disorders of mineral metabolism, 2nd ed. Raven Press, New-York, USA, 1993, pp. 50-54.

[25] Lengemann F.W., Wasserman R.H., Comar C.L., Studies on the enhancement of radiocalcium and radiostrontium absorption by lactose in the rat, J. Nutr. 68 (1959) 443-456.

[26] Levenson D.I., Bockman R.S., A review of calcium preparations, Nutr. Rev. 52 (1994) 221-232.

[27] Lewis N.M., Marcus M.S.K., Behling A.R. Greger J.L., Calcium supplements and milk: effects on acid-base balance and on retention of calcium, magnesium and phosphorus, Am. J. Clin. Nutr. 49 (1989) 527-533.

[28] Matsui T., Yano H., Awano T., Harumoto T., Saito Y., The influence of casein phosphopeptides on metabolism of ectopic bone induced by decalcified bone matrix implantation in rats, J. Nutr. Sci. Vitaminol. 40 (1994) 137-145.

[29] Matsui T., Kawakita Y., Yano H., Dietary skim milk powder increases ionised calcium in the small intestine of piglets compared to dietary defatted soybean flour, J. Nutr. 127 (1997) 1357-1361.

[30] Mortensen L., Charles P., Bioavailability of calcium supplements and the effect of vitamin D: comparisons between milk, calcium carbonate, and calcium carbonate plus vitamin D, Am. J. Clin. Nutr. 63 (1996) 354-357.

[31] Mosekilde L., Weisbrode S.E., Safron J.A., et al. Calcium-restricted ovariectomized Sinclair S-1 minipigs: an animal model of osteopenia and trabecular plate perforation, Bone 14 (1993) 379-382. 
[32] Noblet J., Fortune H., Shi X.S., Dubois S., Prediction of net energy value of feeds for growing pigs, J. Anim. Sci. 72 (1994) 344-354.

[33] Partridge I.G., A comparison of defluorinated rock phosphate and dicalcium phosphate, in diets containing either skim milk powder or soya bean meal as the main protein supplement, for early-weaned pigs, Anim. Prod. 32 (1981) 67-73.

[34] Pointillart A., Phytates, phytases: leur importance dans l'alimentation des monogastriques, INRA Prod. Anim. 7 (1994) 29-39.

[35] Pointillart A., Guéguen L., Absence d'effet de l'incorporation d'un phosphopeptide du lait sur l'utilisation du calcium et du phosphore chez le jeune porc, Reprod. Nutr. Dev. 29 (1989) 477-486.

[36] Pointillart A., Guéguen L., Calcium bioavailability in pigs fed a dry milk-based diet versus a standard diet containing calcium citrate malate, in: Schlemmer U. (Ed.), Bioavailability' 93: Nutritional, chemical and food processing implications of nutrient availability, Karlsruhe, Germany, BFE, 1993, pp. 200-204.

[37] Pointillart A., Guéguen L., Meal-feeding and phosphorus ingestion influence calcium bioavailability evaluated by calcium balance and bone breaking strength in pigs, Bone and Mineral 21 (1993) 75-81

[38] Pointillart A., Cayron B., Guéguen L., Utilisation du calcium et du phosphore et minéralisation osseuse chez le porc consommant du yaourt, Sci. Aliments 6 (1986) 15-30.

[39] Pointillart A., Colin C., Lacroix H., Guéguen L., Mineral bioavailability and bone mineral contents in pigs given calcium carbonate postprandially, Bone 17 (1995) 357-362.

[40] Pointillart A., Denis I., Colin C., Lacroix H., Vitamin C supplementation does not modify bone mineral content or mineral absorption in growing pigs, J. Nutr. 127 (1997) 1514-1518.

[41] Ranhotra G.S., Gelroth J.A., Torrence J.A., Bock M.A., Winterringer G.L., Bread (white and whole wheat) and nonfat dry milk as sources of bioavailability calcium for rats, J. Nutr. 111 (1981) 2081-2086.

[42] Recker R.R., Bammi A., Barger-Lux M.J., Heaney R.P., Calcium absorbability from milk products, and imitation milk, and calcium carbonate, Am. J. Clin. Nutr. 47 (1988) 93-95.

[43] Risteli J., Elomaa I., Niemi S., Novamo A., Risteli L., Radioimmunoassay for the pyridinoline cross-inked carboxyterminal telopeptide of type 1 collagen: A new marker of bone resorption, Clin. Chem. 39 (1993) 635-640.

[44] Schaafsma G., Visser R., Nutritional interrelationships between calcium, phosphorus and lactose in rats, J. Nutr. 110 (1980) 1101-1111.

[45] Schandler R.J., Abrams S.A., Sheng H.P., Calcium and phosphorus deficiencies affect mineral distribution in neonatal miniature piglets, Am. J. Clin. Nutr. 54 (1991) 420-424.

[46] Scholz-Ahrens K.E., Kopra N., Barth C.A., Effect of casein phosphopeptides on utilization of calcium in minipigs and vitamin D deficient rats, Z. Ernährungswiss. 29 (1990) 295-298.

[47] Sève B., Alimentation du porc en croissance : intégration des concepts de protéine idéale, de disponibilité digestive des acides aminés et d'énergie nette, INRA Prod. Anim. 7 (1994) 275-291.

[48] Sheikh M.S., Santa Ana C.A., Nicar M.J., Schiller L.R., Fordtran J.S., Gastrointestinal absorption of calcium from milk and calcium salts, N. Engl. J. Med. 317 (1987) 532-536.

[49] Smith K.T., Heaney R.P., Flora L., Hinders S.M., Calcium absorption from a new calcium delivery system (CCM), Calcif. Tissue Int. 41 (1987) 351-352.

[50] Snedecor G., Cochran W., Méthodes statistiques, Acta, Paris, France, 1971.

[51] Tsuchita H., Goto T., Yonehara Y., Kuwata T., Calcium and phosphorus availability from casein phosphopeptides in male growing rats, Nutr. Res. 15 (1995) 1657-1667.

[52] Walker W.R., Maxwell C.V., Owens F.N., Buchanan D.S., Milk versus soybean protein sources for pigs: I. Effects on performance and digestibility, J. Anim. Sci. 63 (1986) 505-512.

[53] Walker W.R., Maxwell C.V., Owens F.N., Buchanan D.S., Milk versus soybean protein sources for pigs: II. Effects on amino acid availability, J. Anim. Sci. 63 (1986) 513-524.

[54] Whiting S.J., Draper H.H., The role of sulfate in the calciuria of high protein diets in adult rats, J. Nutr. 110 (1980) 212-222.

[55] Wilson H.D., Schedl H.P., Effects of casein and fibrin on calcium absorption and calcium homeostasis in the rat, Dig. Dis. Sci. 26 (1981) 237-242.

[56] Wynkel A., Hanrotel C., Wuillai A., Chanard J., Intestinal calcium absorption from mineral water, Miner. Electrolyte Metab. 23 (1997) 88-92. 